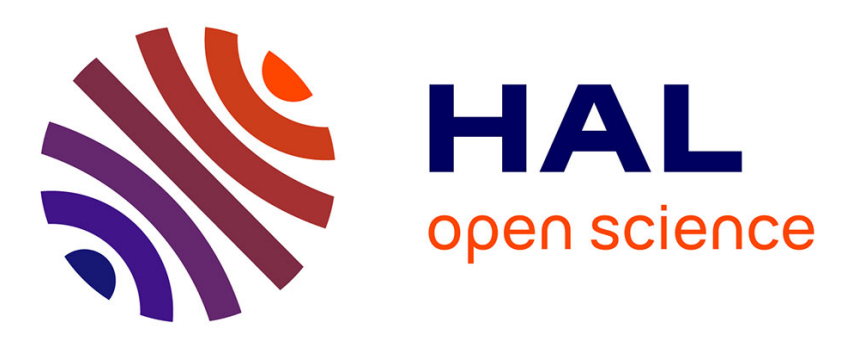

\title{
A new sulfonylated flavonoid and other bioactive compounds isolated from the aerial parts of Cotula anthemoides L.
}

Wafa Tadrent, Abdulmagid Alabdul Magid, Ahmed Kabouche, Dominique Harakat, Laurence Voutquenne-Nazabadioko, Zahia Kabouche

\section{To cite this version:}

Wafa Tadrent, Abdulmagid Alabdul Magid, Ahmed Kabouche, Dominique Harakat, Laurence Voutquenne-Nazabadioko, et al.. A new sulfonylated flavonoid and other bioactive compounds isolated from the aerial parts of Cotula anthemoides L.. Natural Product Research, 2016, 31 (12), pp.1437-1445. 10.1080/14786419.2016.1261342 . hal-01834071

\section{HAL Id: hal-01834071 \\ https://hal.univ-reims.fr/hal-01834071}

Submitted on 5 Nov 2021

HAL is a multi-disciplinary open access archive for the deposit and dissemination of scientific research documents, whether they are published or not. The documents may come from teaching and research institutions in France or abroad, or from public or private research centers.
L'archive ouverte pluridisciplinaire HAL, est destinée au dépôt et à la diffusion de documents scientifiques de niveau recherche, publiés ou non, émanant des établissements d'enseignement et de recherche français ou étrangers, des laboratoires publics ou privés. 


\title{
A new sulfonylated flavonoid and other bioactive compounds isolated from the aerial parts of Cotula anthemoides L.
}

Wafa Tadrent ${ }^{\mathrm{a}}$, Abdulmagid Alabdul Magid ${ }^{\mathrm{b} *}$, Ahmed Kabouche ${ }^{\mathrm{a}}$, Dominique Harakat ${ }^{\mathrm{c}}$, Laurence Voutquenne-Nazabadioko ${ }^{\mathrm{b}}$ and Zahia Kabouche $\mathrm{a}^{\mathrm{a}^{*}}$

${ }^{a}$ Université des frères Mentouri Constantine, Département de chimie, Laboratoire d'Obtention des Substances Thérapeutiques (L.O.S.T), Campus Chaabet-Ersas, 25000 Constantine, Algeria.

${ }^{\mathrm{b}}$ Groupe Isolement et Structure, Institut de Chimie Moléculaire de Reims (ICMR), CNRS UMR 7312, UFR de Pharmacie, BP 1039, 51687 Reims, France.

${ }^{\mathrm{c}}$ Service Commun d'Analyses, Institut de Chimie Moléculaire de Reims (ICMR), CNRS UMR 7312, Bât. 18 B.P.1039, 51687

Reims, France.

*Corresponding author: Prof. Zahia KABOUCHE; E-mail: zkabouche@ yahoo.com; Tel/fax: 213-31811100

\begin{abstract}
A new sulfonyl flavonol glucoside, quercetin 6'-[propanoic acid-(2-acetoxy-3-sulfonyl)]-3'-O- $\beta$-D-glucopyranoside (1) was isolated from the aerial parts of Cotula anthemoides L. in addition to fifteen known compounds (2-16). The structure elucidation of these compounds was based on analyses of spectroscopic data including 1D-, 2D-NMR and HR-ESI-MS techniques and by comparing their NMR data with those reported in the literature. These compounds were evaluated for their DPPH radical scavenging and tyrosinase inhibitory activity. Compound 6 showed a high DPPH radical scavenging with $\mathrm{EC}_{50}$ value of $9.1 \pm 0.4$. Compound $\mathbf{1 1}, \mathbf{9}$ and $\mathbf{1}$ exhibited a mild tyrosinase inhibitory activity with $\mathrm{IC}_{50}$ values of $85 \pm 0.8,95 \pm 1.5$ and $100 \pm 0.5$, respectively.
\end{abstract}

Keywords: Cotula anthemoides, Asteraceae, antioxidant activity, tyrosinase inhibitory activity.

\section{Introduction}

The genus Cotula (Asteraceae) consists of approximately 80 species, among them, three are distributed in Algeria (Ozenda, 1958). Plants of this genus are used in traditional medicine for their anti-inflammatory, analgesic, antiseptic properties (Jana et al., 1992) and as aromatic and digestive substance in tea (Bellakhdar, 1997). In addition, it has been reported as antipyretic (Larhsini et al., 2002), bacteriostatic (Jana et al., 1992), antiprotozoal (Markouk et al., 1999) and anticorrosive (Benmenine et al., 2011). Several flavonoids (Ahmed et al., 1987; Mahran et al., 1976), alkaloids (Mahjoub et al., 2012), sesquiterpene lactones (Jakupovitch et al., 1988; Metwalli et al., 1986) and coumarins (Greger et al., 1985) were isolated from this genus. Cotula anthemoides $\mathrm{L}$ commonly known as 'Babunaj' in Algeria is used for colic and as a remedy for head and chest colds (Abhay and Tripathi, 2011). Previous phytochemical investigation on $C$. anthemoides led to the isolation of coumarin derivatives: 6-methoxy-2-oxo-2H-chromene-8carboxylic acid methyl ester, $\alpha$-pinene, ursolic acid and gibberellic acid (Showkat, 2012), 5-hydroxy-6,3',4'trimethoxyisoflavone-7- $O$ - $\beta$-D-glucopyranosyl $(1 \rightarrow 6)-\alpha-$ L-rhamnopyranoside and 5,7-dihydroxy-6,8-dimethyl-3- methoxyflavone-7- $O$ - $\beta$-D-galactopyranosyl-( $(1 \rightarrow 2)-\alpha-\mathrm{L}-$ rhamnopyranoside (Yadava and Barsainya, 1998). The present work describes the isolation and structural identification of sixteen compounds from $C$. anthemoides that grows wild in Algerian Sahara; fourteen are reported here for the first time from the aerial parts of Cotula anthemoides $\mathrm{L}$. In addition, the radical scavenging ability (DPPH assay) and the tyrosinase inhibitory activity of all compounds were investigated for the first time, from this plant.

\section{Results and discussion}

The $n$ - $\mathrm{BuOH}$ extract of the aerial parts of $C$. anthemoides was separated by combined chromatographic methods to obtain a new sulfonyl flavonol glucoside (1) (Fig. 1), in addition to fifteen known compounds (2-16) which were elucidated as luteolin-7- $O$ - $\beta$-D-glucopyranoside (2) (Furkan et al., 2012), vicenin 2 (3) (Yinrong and Yeap foo, 2000), luteolin-7-O- $\beta$-D-glucuronopyranoside (4) (Tsukasa et al., 2011), apigenin-7-O- $\beta$-Dglucuronopyranoside (5) (Xiao et al., 2006), 6hydroxyluteolin-7- $O-\beta$-D-glucopyranoside (6) (Yinrong and Yeap foo, 2000), isoetin-5'-O- $\beta$-D-glucopyranoside (7) (Alberto et al., 1988), tachioside (8) (Shogo et al., 
1987), pseudolaroside A (9) (Peng et al., 2006), junipediol A 8-O- $\beta$-D-glucopyranoside (10) (Gilles et al., 1997; Arunee et al., 2014), vanillic acid-4-O- $\beta$-Dglucopyranoside (11) (Akiyo et al., 1995), 2-hydroxy-3phenylpropionamide (12) (Zhi-gang et al., 2012), protocatechuic acid (13) (Hui et al, 1998), uridine (14) (Yalçin et al., 2003), tuberonic acid $\beta$-D-glucopyranoside (15) (Baoliang et al., 1993) and rosmarinic acid (Gohari et al., 2009) (Fig.S1) . Their structural assignments were made by HR-ESI-MS, 1D-, and 2D-NMR analyses and by comparison with spectral data from the literature values. To the best of our knowledge, compounds 3-16 were isolated for the first time from the genus Cotula.

Compound $\mathbf{1}$ was isolated as a yellow amorphous powder. The positive HR-ESI-MS showed a molecular ion peak $\mathrm{m} / \mathrm{z} 681.0744 \quad[\mathrm{M}+\mathrm{Na}]^{+}$(calcd for $\mathrm{C}_{26} \mathrm{H}_{26} \mathrm{O}_{18} \mathrm{NaS}$, 681.0744) enabling to determine the molecular formula $\mathrm{C}_{26} \mathrm{H}_{26} \mathrm{O}_{18} \mathrm{~S}$. The UV spectrum revealed absorption bands at 206, 260 and $350 \mathrm{~nm}$. The ${ }^{1} \mathrm{H}$ and ${ }^{13} \mathrm{C}$ NMR spectra of $\mathbf{1}$ showed characteristic signals indicating the presence of one sugar unit and one flavonol moiety (Ozbek et al., 2015). Signals arising from one anomeric proton at $\delta_{\mathrm{H}} 5.07(1 \mathrm{H}, \mathrm{d}, J=7.4 \mathrm{~Hz})$ and other protons of sugar moiety in the range of $\left(\delta_{\mathrm{H}} 3.5-4.0\right.$ $\mathrm{ppm}$ ) showed the presence of d-glucose with $\beta$ configuration on the basis of the large coupling constants between H-1" to H-5" (Table 1) (Alabdul Magid et al., 2008). Complete assignments of osidic protons and carbons were determined by the analysis of COSY, HSQC and HMBC experiments. The relative configuration of $\beta$-D-glucopyranosyl moiety was further confirmed by analysis of the ROESY correlations from the $\alpha$-axial protons $\mathrm{H}-1 / \mathrm{H}-3$ and $\mathrm{H}-1 / \mathrm{H}-5$. The A-ring of the flavonol was represented by two meta-coupled resonances at $\delta_{\mathrm{H}} 6.26(1 \mathrm{H}$, brs $)$ and $\delta_{\mathrm{H}} 6.38(1 \mathrm{H}$, brs $)$ assigned to $\mathrm{H}-6$ and $\mathrm{H}-8$, respectively. The ${ }^{1} \mathrm{H}$ NMR data (see experimental part) exhibited two singlet signals at $\delta_{\mathrm{H}}$ $7.43(1 \mathrm{H}, \mathrm{s})$ and $\delta_{\mathrm{H}} 7.85(1 \mathrm{H}, \mathrm{s})$ assignable to $\mathrm{H}-5^{\prime}$ and $\mathrm{H}-$ 2 ', respectively, which were correlated in the HSQC spectrum with their aromatic carbons at $\delta_{\mathrm{c}} 119.1$ and $\delta_{\mathrm{c}}$ $113.9 \mathrm{ppm}$, respectively. In addition, one methyl proton appeared at $\delta_{\mathrm{H}} 1.90(3 \mathrm{H}, \mathrm{s})$ together with a set of three aliphatic protons $\delta_{\mathrm{H}} 3.45(1 \mathrm{H}, \mathrm{dd}, J=14.1,6.8 \mathrm{~Hz}), 3.56$ $(1 \mathrm{H}, \mathrm{m})$ and $5.42(1 \mathrm{H}, \mathrm{dd}, J=6.5,4.1 \mathrm{~Hz})$. The ${ }^{1} \mathrm{H}$ and ${ }^{13} \mathrm{C}$ NMR signals of compound $\mathbf{1}$ were completely assigned by a combination of HSQC, HMBC and ${ }^{1} \mathrm{H}-{ }^{1} \mathrm{H}$ COSY experiments. The ${ }^{1} \mathrm{H}-{ }^{1} \mathrm{H}$ COSY correlation between $\mathrm{H}_{2}-3^{\prime \prime \prime}\left(\delta_{\mathrm{H}} 3.45,3.56\right)$ and $\mathrm{H}-2^{\prime \prime \prime}\left(\delta_{\mathrm{H}} 5.42\right)$ and the cross-peaks in the HMBC spectrum (Fig. S17) between $\mathrm{H}_{2}-3^{\prime \prime \prime} / \mathrm{C}-2^{\prime \prime \prime}\left(\delta_{\mathrm{C}} 67.1\right)$ and $\mathrm{C}-1^{\prime \prime \prime}\left(\delta_{\mathrm{C}} 171.5\right)$, H$2^{\prime \prime \prime} / \mathrm{C}-1{ }^{\prime \prime \prime}, \mathrm{C}-3{ }^{\prime \prime \prime}\left(\delta_{\mathrm{C}} 57.2\right)$, and C-4"' $\left(\delta_{\mathrm{C}} 171.3\right)$ and $\mathrm{H}_{3}\left(\delta_{\mathrm{H}}\right.$ $1.90) / C-4^{\prime \prime \prime}$, indicated the presence of propanoic acid-2acetoxy-3-sulfonyl moiety. The chemical shift of C-3"' $\left(\delta_{\mathrm{C}} 57.2\right)$ in addition to the molecular formula indicated a sulfonyl group. The site of linkage of the glucopyranosyl and sulfonyl groups in $\mathbf{1}$ was determined by cross-peaks observed in the HMBC experiment between $\mathrm{H}-1^{\prime \prime}$ of glucose $\left(\delta_{\mathrm{H}} 5.07\right)$ and $\mathrm{C}-3^{\prime}\left(\delta_{\mathrm{C}} 148.9\right)$ of quercetin, and between $\mathrm{H}_{2}-3^{\prime \prime \prime}\left(\mathrm{CH}_{2} \mathrm{SO}_{2}\right)$ of sulfonyl group and $\mathrm{C}-6^{\prime}\left(\delta_{\mathrm{C}}\right.$ 133.6) of quercetin. Thus, the structure of compound $\mathbf{1}$ was characterised as quercetin $6{ }^{\prime}$-[propanoic acid-(2acetoxy-3-sulfonyl)]-3'-O- $\beta$-D-glucopyranoside.

Several biological activities of extracts and essential oils of Cotula were reported however, the biological potential of isolated pure compounds has not been investigated. Thus, the isolated compounds 1-16 were tested for their DPPH radical scavenging and antityrosinase activities.

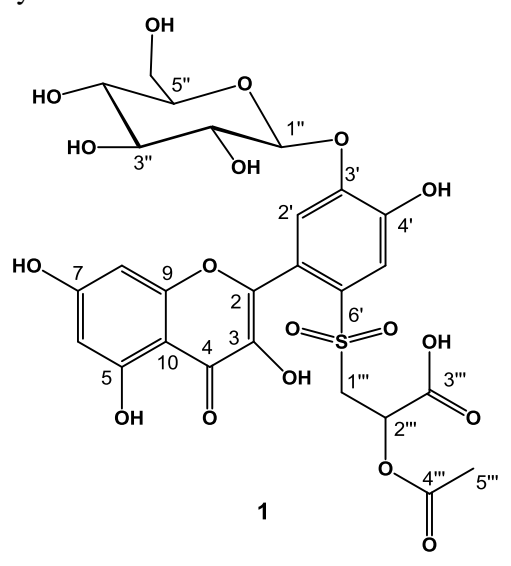

Figure 1: Chemical structure of compound 1 isolated from $C$. anthemoides $\mathrm{L}$.

In order to assess the antioxidative properties of 1-16, the DPPH radical scavenging activity of these compounds was measured. According to the results (Table 2), compounds $\mathbf{1}, \mathbf{2}, \mathbf{4 - 6}, \mathbf{8}$, and 16 have a slightly radical scavenging potential $\left(\mathrm{EC}_{50}\right.$ ranging from 9.1 to $29.9 \mu \mathrm{M})$ compared with ascorbic acid, used as positive control $\left(\mathrm{EC}_{50} 7.4 \mu \mathrm{M}\right)$. The di-OH substitution at $3^{\prime}$ and $4^{\prime}$ in the $\mathrm{B}$ ring is particularly important to the antiradical activity of flavonoids (Arora et al.1998). The trend is consistent with the less active flavonoid $\mathbf{5}$ compared with 4. The free $3-\mathrm{OH}$ was also found to be important for the antioxidant activity of rosmarinic acid $\mathbf{1 6}(3-\mathrm{OH})$ comparing to tachioside $\mathbf{8}\left(3-\mathrm{OCH}_{3}\right)$ (Sawai and Moon, 2000). Comparison of the DPPH radical scavenging activity of 6 with 1, 2 and 4 showed that the presence of the hydroxyl group at C-6 increased the activity. Compounds $\mathbf{2}$ and $\mathbf{4}$ shared a common aglycone which is $3^{\prime}$ and $4^{\prime}$-di-OH substituted in the $\mathrm{B}$ ring (luteolin skeleton), the only difference was in the nature of the group linked at C-7 which was $\beta$-D-glucopyranose (2) and $\beta$-D-glucuronopyranose (4), suggesting that the glucuronic acid may contribute slightly to the increase of the DPPH radical scavenging activity. Thus, we can conclude that the hindrance effect due to the presence of a hydroxy group at C-6, a $\beta$-D-glucose or $\beta$-D-glucuronic acid linked at $\mathrm{C}-7$ in a luteolin skeleton is determinant in the scavenging of the DPPH free radical.

The tyrosinase inhibitory activity of isolated pure compounds 1-16 was performed using L-DOPA as substrate and kojic acid, a well-known strong tyrosinase inhibitor, as a positive control (Demirkiran et al. 2013; 
Kim et al., 2001; Kim and Uyama, 2005; Xie et al., 2003). The results (Table 2) showed that compounds $\mathbf{1 , 9}$ and $\mathbf{1 1}$ exhibited a mild tyrosinase inhibition. The most active compound was $\mathbf{1 1}\left(\mathrm{IC}_{50} 85 \mu \mathrm{M}\right)$ followed by $\mathbf{9}$ $\left(\mathrm{IC}_{50} 95 \mu \mathrm{M}\right)$ and $\mathbf{1}\left(\mathrm{IC}_{50} 100 \mu \mathrm{M}\right)$.

Table 1. Antiradical potential and anti-tyrosinase activity of compounds 1-16 isolated from the aerial parts of $C$. anthemoides $\mathrm{L}$.

\begin{tabular}{|c|c|c|}
\hline Compounds & $\begin{array}{l}\text { DPPH radical scavenging activity } \\
\mathrm{EC}_{50} \pm \text { S.D. }(\mu \mathrm{M})^{\mathrm{a}}\end{array}$ & $\begin{array}{l}\text { Tyrosinase } \\
\text { inhibitory activity } \\
\mathrm{IC}_{50} \pm \text { S.D. }(\mathrm{mM})^{\mathrm{a}}\end{array}$ \\
\hline 1 & $22.8 \pm 0.5$ & $100 \pm 0.5$ \\
\hline 2 & $29.9 \pm 1.3$ & $-{ }^{b}$ \\
\hline 3 & $-{ }^{b}$ & $-{ }^{b}$ \\
\hline 4 & $25.1 \pm 0.7$ & $-{ }^{b}$ \\
\hline 5 & $29.5 \pm 0.1$ & $-\mathrm{b}$ \\
\hline 6 & $9.1 \pm 0.4$ & $-{ }^{b}$ \\
\hline 7 & $-{ }^{\mathrm{b}}$ & $-{ }^{b}$ \\
\hline 8 & $27.6 \pm 1.1$ & $-{ }^{b}$ \\
\hline 9 & $-{ }^{b}$ & $95 \pm 1.5$ \\
\hline 10 & $-{ }^{b}$ & $-\mathrm{b}$ \\
\hline 11 & $-\mathrm{b}$ & $85 \pm 0.8$ \\
\hline 12 & $-\mathrm{b}$ & $-\mathrm{b}$ \\
\hline 13 & $-{ }^{\mathrm{b}}$ & $-{ }^{b}$ \\
\hline 14 & $-{ }^{\mathrm{b}}$ & $-{ }^{b}$ \\
\hline 15 & $-{ }^{b}$ & $-{ }^{b}$ \\
\hline 16 & $12.7 \pm 0.3$ & $-{ }^{\mathrm{b}}$ \\
\hline Ascorbic acid ${ }^{\mathrm{c}}$ & $7.4 \pm 0.05$ & - \\
\hline Kojic Acid ${ }^{\mathrm{c}}$ & & $6.4 \pm 0.04$ \\
\hline
\end{tabular}

In summary, one new sulfonyl flavonol glucopyranoside, along with fifteen known compounds, were isolated from the aerial parts of $C$. anthemoides. The DPPH radical scavenging activity assay showed a high activity for compound 6 compared with ascorbic acid used as a positive control. Compounds $\mathbf{1 , 9}$ and $\mathbf{1 1}$ exhibited a mild in vitro mushroom tyrosinase inhibition compared with kojic acid, used as a positive control.

\section{Experimental}

\subsection{General experimental procedures}

NMR spectra were carried in $\mathrm{MeOH}-d_{4}$ and DMSO on Bruker Avance DRX III 500 instruments. HR-ESI-MS experiments were performed using a Micromass Q-TOF micro instrument. Biological assays were read on a Fluostar Omega microplate reader (BMG labtech), the amounts for DPPH assay were $100 \mu \mathrm{L}(95 \mu \mathrm{L}$ DPPH solution and $5 \mu \mathrm{L}$ sample) and for tyrosinase inhibitory activity are $300 \mu \mathrm{L}(100 \mu \mathrm{L}$ of sample, $100 \mu \mathrm{L}$ of mushroom tyrosinase solution and $100 \mu \mathrm{L}$ of L-dopa). 96-well polystyrene microliter clear plates were used. Thin layer chromatography (TLC) was performed on precoated silica-gel $60 \mathrm{~F}_{254}$ Merck and compounds were observed under UV light at 254 and $365 \mathrm{~nm}$ or visualized by spraying the dried plates with $50 \% \mathrm{H}_{2} \mathrm{SO}_{4}$, followed by heating. $\mathrm{CC}$ was carried out on Kieselgel 60 (63-200 mesh) or LiChroprep RP-18 (40-63 mm) Merck. HPLC was performed on a Dionex apparatus equipped with an ASI-100 autosampler, an Ultimate 3000 pump, a diode array detector UVD 340 S and Chromeleon software. RP18 column (Phenomenex 250x15 mm, Luna $5 \mu$ ) was used for semi-preparative HPLC with binary gradient eluent $\left(\mathrm{H}_{2} \mathrm{O}(\mathrm{pH} 2.4\right.$ with trifluoroacetic acid (TFA)); $\mathrm{MeCN})$ and a flow rate of $4 \mathrm{~mL} / \mathrm{min}$; the chromatogram was monitored at 205, 210, 254, and $360 \mathrm{~nm}$. Absorbance $\mathrm{Ab}$ values in the DPPH free radical scavenging and antityrosinase assay were read on a Fluostar omega microplate reader (BMG labtech).

\subsection{Plant material}

The aerial parts of $C$. anthemoides $\mathrm{L}$. were collected in March 2012 from Tinguentourine, Ain Amenas, Eastern Algerian Sahara. The plant has been authenticated by Prof. Gérard De Belair (Annaba University, Algeria) and a voucher specimen (LOST Ca03/12) was deposited at the herbarium of the Laboratory of Therapeutic Substances (LOST), Faculty of Sciences, Université des Frères Mentouri-Constantine-Algeria.

\subsection{Extraction and isolation}

The powdered dry aerial parts of C. anthemoides (1400 g) were macerated at room temperature in methanol $80 \%$ $(3 \times 7.5 \mathrm{~L}, 24 \mathrm{~h})$. The extract was concentered under low pressure, diluted with $\mathrm{H}_{2} \mathrm{O}(560 \mathrm{~mL})$, then successively extracted with petroleum ether $(\mathrm{PE})(3 \times 300 \mathrm{~mL})$, chloroform $(3 \times 300 \mathrm{~mL})$, ethyl acetate $(3 \times 300 \mathrm{~mL})$, and $n$-butanol $(3 \times 300 \mathrm{~mL})$. After evaporation of the solvents, $0.4 \mathrm{~g}$ of PE, $1.5 \mathrm{~g}$ of $\mathrm{CHCl}_{3}, 0.55 \mathrm{~g}$ of EtOAc and $21.7 \mathrm{~g}$ of $n$ - $\mathrm{BuOH}$ extracts were obtained. The $n$ - $\mathrm{BuOH}$ extract was subjected to VLC over polyamid SC6 $(9 \mathrm{~cm} \times 5 \mathrm{~cm})$ eluted with toluene-methanol with increasing polarity to give 12 fractions (F1-F12 respectively). Fractions F6-7 were combined $(1.4 \mathrm{~g})$ and subjected to HPLC preparative using (10-25\% $\mathrm{MeCN}$ in $60 \mathrm{~min}$ ) to yield 19 fractions. Frs [4-6] (35.5 mg) were purified by semi-prep. HPLC (5-15\% MeCN, in $20 \mathrm{~min}$ ) affording compounds $14\left(\mathrm{R}_{\mathrm{t}} 9.9 \mathrm{~min}, 4 \mathrm{mg}\right)$ and $\mathbf{8}\left(\mathrm{R}_{\mathrm{t}} 13.8 \mathrm{~min}, 3 \mathrm{mg}\right)$. Frs [710] $(36 \mathrm{mg})$ were purified by semi-prep. HPLC $(5-15 \%$ $\mathrm{MeCN}$, in $20 \mathrm{~min})$ yielding compounds $9\left(\mathrm{R}_{\mathrm{t}} 16.5 \mathrm{~min}, 7\right.$ $\mathrm{mg})$ and $10\left(\mathrm{R}_{\mathrm{t}} 21.5 \mathrm{~min}, 4 \mathrm{mg}\right)$. Frs [11-12] (26.7mg) were purified by semi-prep. HPLC (10-25\% MeCN, in 20 min) leading to compound $\mathbf{1 1}\left(\mathrm{R}_{\mathrm{t}} 6.3 \mathrm{~min}, 3.2 \mathrm{mg}\right)$. Frs [26-27] $(51 \mathrm{mg})$ were purified by semi-prep. HPLC (15$35 \% \mathrm{MeCN}$, in $20 \mathrm{~min})$ to afford compounds $\mathbf{1 2}\left(\mathrm{R}_{\mathrm{t}} 8.5\right.$ $\mathrm{min}, 1.6 \mathrm{mg})$ and $15\left(\mathrm{R}_{\mathrm{t}} 16.5 \mathrm{~min}, 4.7 \mathrm{mg}\right)$. Frs [36-44] (42 mg) were purified by semi-prep. HPLC (10-40\% $\mathrm{MeCN}$, in $25 \mathrm{~min})$ yielding compounds $\mathbf{1 6}\left(\mathrm{R}_{\mathrm{t}} 25.9 \mathrm{~min}\right.$, $4.2 \mathrm{mg})$. The combined fractions F9-11 $(827 \mathrm{mg})$ were subjected to a preparative HPLC $(10-40 \% \mathrm{MeCN}$ in 60 min) to obtain 35 fractions. Frs [7-13] $(50.3 \mathrm{mg})$ were purified by semi-prep. HPLC (15-35\% MeCN, in $20 \mathrm{~min}$ ) yielding compounds $1\left(\mathrm{R}_{\mathrm{t}} 13.1 \mathrm{~min}, 7 \mathrm{mg}\right), \mathbf{4}\left(\mathrm{R}_{\mathrm{t}} 14.2\right.$ $\mathrm{min}, 5 \mathrm{mg})$ and $\mathbf{1 6}\left(\mathrm{R}_{\mathrm{t}} 18.2 \mathrm{~min}, 1.4 \mathrm{mg}\right)$. Frs [14-28] $(46.2 \mathrm{mg})$ were purified by semi-prep. HPLC (15-35\% MeCN, in $20 \mathrm{~min}$ ) leading to compounds $3\left(\mathrm{R}_{\mathrm{t}} 8.0 \mathrm{~min}\right.$, $4.0 \mathrm{mg}), 2\left(\mathrm{R}_{\mathrm{t}} 13.7 \mathrm{~min}, 3.5 \mathrm{mg}\right)$ and $\mathbf{5}\left(\mathrm{R}_{\mathrm{t}} 15.1 \mathrm{~min}, 4.1\right.$ $\mathrm{mg})$. Compound 6 (17.1 min, $9.2 \mathrm{mg}$ ) was purified from 
Frs [28-29] by semi-prep. HPLC (15-35\% MeCN, in 20 $\mathrm{min})$. Frs [30-32] were purified by semi-prep. HPLC (15$35 \% \mathrm{MeCN}$, in $30 \mathrm{~min})$ affording compounds $\mathbf{1 3}\left(\mathrm{R}_{\mathrm{t}} 6.3\right.$ $\mathrm{min}, 1 \mathrm{mg})$ and $7\left(\mathrm{R}_{\mathrm{t}} 26.4 \mathrm{~min}, 11.2 \mathrm{mg}\right)$.

\subsubsection{Quercetin 6'-[propanoic acid-(2-acetoxy-3-} sulfonyl)]-3'-O- $\beta$-D-glucopyranoside

Yellow amorphous powder; $[\alpha]_{\mathrm{D}}{ }^{20}+26.8$ (c 0.25 , MeOH). UV (MeOH) $\lambda_{\max }(\mathrm{ab}):$.206 (2.1), 260 (1.3), 350 (0.55). ${ }^{1} \mathrm{H}$ NMR $\left(500 \mathrm{MHz}, \mathrm{CD}_{3} \mathrm{OD}\right): \delta_{\mathrm{H}} 6.26$ (brs, H-6), 6.38 (brs, H-8), 7.85 (s, H-2'), 7.43 (s, H-5'), 5.07 (d, $J=$ $\left.7.4 \mathrm{~Hz}, \mathrm{H}-1^{\prime \prime}\right), 3.59$ (dd, $\left.J=8.9,7.4 \mathrm{~Hz}, \mathrm{H}-2 "\right), 3.56$ (t, $J=$ $8.6 \mathrm{~Hz}, \mathrm{H}-3 "), 3.52$ (t, $J=8.6 \mathrm{~Hz}, \mathrm{H}-4 "), 3.60$ (m, H-5"), 3.81 (dd, $J=12.2,4.8 \mathrm{~Hz}, \mathrm{H}-6 " \mathrm{a}), 4.00$ (dd, $J=12.2,2.5$ Hz, H-6"b), 5.42 (dd, $J=6.5,4.1, \mathrm{H}-2$ "'), 3.45 (dd, $J=$ 14.1,6.8, H- 3"'a), 3.56 (m, H- 3"'b), 1.90 (s, H- 5"'). ${ }^{13} \mathrm{C}$ NMR (125 MHz, CD 3 OD) : $\delta 145.2$ (C-2), 138.9 (C-3), 177.6 (C-4), 162.9 (C-5), 99.8 (C-6), 166.1 (C-7), 94.7 (C-8), 158.4 (C-9), 105.1 (C-10), $125.4\left(\mathrm{C}-1^{\prime}\right), 113.9$ (C$\left.2^{\prime}\right), 148.9\left(\mathrm{C}-3^{\prime}\right), 151.1\left(\mathrm{C}-4^{\prime}\right), 119.1\left(\mathrm{C}-5^{\prime}\right), 133.6\left(\mathrm{C}-6^{\prime}\right)$, 103.0 ( C-1"), 74.7 (C-2"), 77.6 (C-3"), 71.0 (C-4"), 78.3 (C-5"), 62.2 (C-6"), 57.2 (C-1"'), 67.1 (C-2"'), 171.5 (C3"'), 171.3 (C-4"'), 20.2 (C-5"'). HR-ESI-MS [M+Na] ${ }^{+}$ $m / z 681.0744$ (calcd for $\mathrm{C}_{26} \mathrm{H}_{26} \mathrm{O}_{18} \mathrm{NaS}, 681.0744$ ).

\subsubsection{Acid hydrolysis}

A part of the $n$ - $\mathrm{BuOH}$ extract (300 mg) was refluxed (90 ${ }^{\circ} \mathrm{C}$ ) with $10 \mathrm{~mL}$ of $2 \mathrm{M}$ TFA for $3 \mathrm{~h}$. After extraction with ethyl acetate $(3 \times 10 \mathrm{~mL})$, the aqueous layer was evaporated to furnish the monosaccharide residue (100 $\mathrm{mg}$ ). Two sugars were identified as glucose and glucuronic acid by comparison with authentic samples on TLC in MeCOEt:iso-PrOH: $\mathrm{Me}_{2} \mathrm{CO}: \mathrm{H}_{2} \mathrm{O}$ (20:10:7:6). The monosaccharide residue $(100 \mathrm{mg})$ was subjected to a preparative TLC using the same solvent. The optical rotation of each purified sugar was measured and compared with authentic samples to afford D-glucose and D-glucuronic acid.

\subsection{Biological activities}

\subsubsection{DPPH free radical scavenging assay}

The scavenging activity of isolated compounds against DPPH was investigated by spectrophotometric methodology, as previously described (Gossan et al.,
2015). Briefly, $5 \mu \mathrm{L}$ of either the standard or sample solutions (dissolved in DMSO) was mixed with $95 \mu \mathrm{L}$ of DPPH solution $(158 \mu \mathrm{M}$, dissolved in absolute EtOH). After mixing gently and incubating for $30 \mathrm{~min}$ at $37^{\circ} \mathrm{C}$, the optical density was measured at $\lambda 515 \mathrm{~nm}$. The percentage of absorbance inhibition at $\lambda 515 \mathrm{~nm}$ was calculated using the following equation: $\%$ inhibition $\left[\left(\mathrm{Ab}_{\text {control }}-\mathrm{A} \mathrm{b}_{\text {sample }}\right) / A b_{\text {control }}\right] \times 100$. DPPH solution in EtOH was used as a control. The curve of the \% scavenging activity against the concentration of sample was prepared by the MSExcel based program to obtain the $\mathrm{EC}_{50}$. All the tests were conducted in triplicate. The experimental data were expressed as mean \pm standard deviation.

\subsubsection{Tyrosinase enzyme assay}

Tyrosinase activity inhibition was determined by spectrophotometric methodology, as previously described (Ngoc et al., 2009). $100 \mu \mathrm{L}$ of each test compound solution (dissolved in 10\% DMSO) was added to 96-well plate then mixted with $100 \mu \mathrm{L}$ of mushroom tyrosinase solution $(135 \mathrm{U} / \mathrm{ml}$ mushroom tyrosinase in phosphate buffer solution (PBS, pH 6.8)). After pre-incubation at 25 ${ }^{\circ} \mathrm{C}$ for $10 \mathrm{~min}, 100 \mu \mathrm{L}$ of L-dopa (0.5 mM, PBS pH 6.8) were added into 96-well plate. The reaction mixture was incubated for another $5 \mathrm{~min}$ at $25{ }^{\circ} \mathrm{C}$. The amount of dopachrome in the mixture was determined by the measurement of the absorbance of each well at $475 \mathrm{~nm}$. The inhibitory percentage of tyrosinase was calculated according to the following equation: $\%$ inhibition $=\{[(\mathrm{A}$ - B) - (C - D)]/ (A - B) $\} \times 100$. A: Ab at $475 \mathrm{~nm}$ without test substance; $\mathrm{B}: \mathrm{Ab}$ at $475 \mathrm{~nm}$ without test substance and tyrosinase; $\mathrm{C}$ : $\mathrm{Ab}$ at $475 \mathrm{~nm}$ with test substance; $\mathrm{D}$ : $\mathrm{Ab}$ at $475 \mathrm{~nm}$ with test substance, but without tyrosinase. Kojic acid was used as positive control agent. All the tests were conducted in triplicate and $\mathrm{IC}_{50}$ was determined by interpolation of concentration $\%$ inhibition curve obtained by MSExcel based program. The experimental data were expressed as mean \pm standard deviation.

\section{Acknowledgements}

The authors are grateful to DGRSDT and ATRSS (MESRS, Algeria), to university Frères Mentouri-Constantine and to Groupe Isolement et Structure of the Institut de Chimie Moléculaire de Reims (ICMR), France for financial support.

\section{Supporting Information}

HR-ESI-MS, ${ }^{1} \mathrm{H}$ and ${ }^{13} \mathrm{C}$ NMR, COSY, HMBC, HSQC and ROESY spectra for compound $\mathbf{1 .}$

\section{References}

Abhay KP, Tripathi NN. 2011. Aromatic plants of Gorakhpur division: Their antimycoticproperties and medicinal value. Int J Pharm Sci Rev Res. 7 (2): 142147.
Ahmed AA, EL-Sayed N, EL-Negoumi S, Mabry JT. 1987. Flavonoids of Cotula cinerea. J Nat Prod. 50 (3): 519-520.

Akiyo S, Maksut C, Takashi M. 1995. Hydroxyl benzoic acids from Boreava orientalis. Phytochemistry. 40 (1): 257-261. 
Alabdul Magid A, Voutquenne-Nazabadioko L, Bontemps G, Litaudon M, Lavaud C. 2008. Tyrosinase inhibitors and sesquiterpene diglycosides from Guioa villosa. Planta Med. 74: 55-60.

Alberto Marco J, Barbera O, Rodriguez S, Domingo C, Adell J. 1988. Flavonoïds and other phenolics from Artemisia hispanica. Phytochemistry. 27 (10): 31553159.

Arora A, Nair MG, Strasburg GM. 1998. Structureactivity relationships for antioxidant activities of a series of flavonoids in a liposomal system. Free Radic Biol Med. 24: 1355-1363.

Arunee S, Kaoru U, Hiroshi N, Pharkphoom P. 2014. Identification of a new angiotensin-converting enzyme (ACE) inhibitor from Thai edible plants. Food Chem. 165: 92-97.

Baoliangn C, Motoyuki N, Junei K, Toshihiro N. 1993. Chemical constituents of Astragali semen. Chem Pharm Bull. 41 (1): 178-182.

Bellakhdar J. 1997. La Pharmacopée marocaine traditionnelle. Vol 1, Ibis press. Paris.

Benmenine AK, Ouahrani MR, Gherraf N, Sekirifa ML, Baameur L. 2011. Potentiodynamic investigation of the anticorrosive action of Cotula cinerae extracts on mild steel X 52 in $20 \% \mathrm{H}_{2} \mathrm{SO}_{4}$ Solution. J Chem Pharm Res. 3 (3) : 666-669.

Chang TS. 2009. An updated review of tyrosinase inhibitors. Int J Mol Sci. 10: 2440-2475.

Demirkiran O, Sabudak T, Ozturk M, Topcu G. 2013. Antioxidant and tyrosinase inhibitory activities of flavonoids from Trifolium nigrescens subsp petrisavi. J Agr Food Chem. 61: 12598-12603.

Furkan O, Özlem B, Derya Y, Tuğba B, Zuhal G, Medine G. 2012. Isolation of some luteolin derivatives from Mentha longifolia (L.) Hudson sbsps longifolia and determination of their genotoxic potencies. Food Chem. 135: 764-769.

Gilles C, Daovy PA, Albert JC, Joseph V, Noel P. 1997. Three phenylpropanoids from Juniperus phonicea. Phytochemistry. 64 (6): 1169-1173.

Gohari AR, Saeidnia S, Shahverdi AR, Yassa N, Malmir M, Mollazade K, Naghinejad AR. 2009. Phytochemistry and antimicrobial compounds of Hymenocrater calycinus. Eur Asia J Bio Sci. 3: 6468.

Gossan DPA, Alabdul Magid A, Yao-Kouassi PA, Coffy AA, Harakat D, Voutquenne-Nazabadioko L. 2015. New acylated flavonol glycosides from the aerial parts of Gouania longipetala. Phytochem Lett. 11: 306-310.

Greger H, Otmar H. 1985. Sesquiterpene coumarin ethers and polyacetylenes from Brocchia cinerea. Phytochemistry. 24 (1): 85-88.

Hui-Li Z, Akito N, Harumi O, Hajim M, Jinsaku S. 1998. Sesquiterpene glycosides from Cotton oil cake. Phytochemistry. 48 (4): 665-668.
Jana M, Lazrek HB, Markouk M. 1992. Effets bactériostatiques des extraits flavoniques de Cotula cinerea. El Bayrounia Rev Mar Pharm. 8 (2): 89-96.

Jakupovic J, Aad MA, Eid F, Bohlmann F, Mungay MG. 1988. Further glaucolides and other sesquiterpene lactones from Brocchia cinerea. Phytochemistry. 27 (7): 2219-2224.

Kim DS, Kim SY, Moon SJ, Chung JH, Kim KH, Cho KH. 2001. Ceramide inhibits cell proliferation through Akt/PKB inactivation and decreases melanin synthesis in Mel-Ab cells. Pigm Cell Res. 14: $110-$ 115.

Kim D, Park J, Kim J, Han C, Yoon J, Kim N. 2006. Flavonoids as mushroom tyrosinase inhibitors: A fluorescence quenching study. J Agric Food Chem. 54: 935-941.

Kim JY, Uyama H. 2005. Tyrosinase inhibitors from natural and synthetic sources: Structure, inhibition mechanism and perspective for the future. Cell Mol Life Sci. 62: 1707-1723.

Larhsini M, Markouk M, Jouhari JT, Bekkouche K, Lazrek HB, Jana M. 2002. The antipyretic activity of some Moroccan medicinal plants. Phytother Res. 16 (1): S97-98.

Mahjoub MA, Ammar S, Majouli K, Mighri Z. 2012. Two new alkaloids and a new polyphenolic compound from Cotula coronopifolia. Chem Nat Compd. 47 (6): 955-958.

Mahran GH, Salah Ahmed M, Ansari SA. 1976. A study of the flavonoid content of Cotula cinerea. Bull Fac Pharm Cairo Univ. 14 (1): 237-246.

Markouk M, Lazrek HB, Jana M. 1999. Analgesic effects from Cotula cinerea. Phytother Res. 13: 229-230.

Matsuda H, Higashino M, Chen W, Tosa H, Iinuma M, Kubo M. 1995. Studies of cuticle drugs from natural sources. III. Inhibitory effect of Myrica rubra on melanin biosynthesis. Biol Pharm Bull. 18: 11481150.

Metwally MA, EL-Dahmi S, Jakupovic J, Bohlmann F, Dawidar AM, Metwally SA. 1985. Glaucolide-like sesquiterpene lactones from Cotula cinerea. Phytochemistry. 25 (1): 255-257.

Ngoc TM, Lee I, Ha DT, Kim HJ, Min BS, Bae KH. 2009. Tyrosinase-inhibitory constituents from the twigs of Cinnamomum cassia. J Nat Prod. 72: 12051208.

Ozenda P. 1958. Flore du Sahara septentrional et central, CNRS, Paris.

Özbeka H, Güvenalpa Z, Kuruüzüm-Uzb A, Kazazc C, Ömür Demirezerb L. 2016. $\beta$ Hydroxydihydrochalcone and flavonoid glycosides along with triterpene saponin and sesquiterpene from the herbs of Pimpinella rhodantha Boiss. Nat Prod Res. 30 (7): 750-754.

Peng L, Hongzhu G, Yin T, Qiao W, Dean G. 2006. Benzoic acid allopyranosides from the bark of Pseudolarix kaempferi. Phytochemistry. 67: 13951398. 
Sawai Y, Moon JH. 2000. NMR analytical approach to clarify the molecular mechanisms of the antixodative and radical-scavenging activities of antioxidants in tea using 1, 1-diphenyl-2-picrylhydrazyl. J Agric Food Chem. 48: 6247-6253.

Shogo I, Manami S, Hiroshi K, Hideaki O, Kazuo Y. 1987. Aromatic glycosides from Berchemia racemosa. Phyrochemistry. 26 (10): 2811-2814.

Showkat R. 2012. Chemoprofiling of medicinal plants and value addition of their principle constituents through synthetic modifications. Kashmir, Srinagar.

Tsukasa I, Hiroaki S, Junichi K. 2011. Flavonoids from the leaves of Vitex rotundifolia (Verbenaceae) and their qualitative and quantitative comparison between Coastal and Inland populations. Bull Natl Mus Nat Sci. 37 (2): 87-94.

Xiao JB, Ren FL, Xu M. 2006. Flavones from Marchantia convoluta: Isolation of apigenin-7-O- $\beta$ D-glucuronide and 5-hydroxyl-7-methoxyl-2methylchromone. J Pharm All Sci. 3 (1): 310-313.
Xie LP, Chen QX, Huang H, Wang HZ, Zhang RQ. 2003. Inhibitory effects of some flavonoids on the activity of mushroom tyrosinase. Biochemistry. 68: 487-491.

Yadava RN, Barsainya D. 1998. A novel flavone glycoside from the seeds of Cotula anthemoides. Fitoterapia. 69 (5): 437-438.

Yalçin FN, Ersöz T, Akbay P, Çaliş İ. 2003. Phenolic, megastigmane, nucleotide, acetophenon and monoterpene glycosides from Phlomis samia and $P$. carica. Turk J Chem. 27: 703-711.

Yinrong L, Yeap foo L. 2000. Flavonoids and phenolic glucosides from Salvia officinalis. Phytochemistry. 55: 263-267.

Zhi-gang W, Hai-yan X, Qiong M, Ye C, Jian-nan M, Chao-mei M. 2012. Isolation, identification and quantification of unsaturated fatty acids, amides, phenolic compounds and glycoalkaloids from Potatoes peel. Food Chem. 135: 2425-2429. 